\title{
A Short Guide to SDI Profiling at ORNL
}

Herbert S. Pomerance

\section{OAK RIDGE NATIONAL LABORATORY}




\section{DISCLAIMER}

This report was prepared as an account of work sponsored by an agency of the United States Government. Neither the United States Government nor any agency Thereof, nor any of their employees, makes any warranty, express or implied, or assumes any legal liability or responsibility for the accuracy, completeness, or usefulness of any information, apparatus, product, or process disclosed, or represents that its use would not infringe privately owned rights. Reference herein to any specific commercial product, process, or service by trade name, trademark, manufacturer, or otherwise does not necessarily constitute or imply its endorsement, recommendation, or favoring by the United States Government or any agency thereof. The views and opinions of authors expressed herein do not necessarily state or reflect those of the United States Government or any agency thereof. 


\section{DISCLAIMER}

Portions of this document may be illegible in electronic image products. Images are produced from the best available original document. 
Printed in the United States of America: Available from National Technical Information Service

U.S. Department of Commerce

5285 Port Royal Road, Springfield, Virginia 22161

Price: Printed Copy $\$ 4.00$; Microfiche $\$ 2.25$

This report was prepared as an account of work sponsored by the United States Government. Neither the United States nor the Energy Research and Development Administration/United States Nuclear Regulatory Commission, nor any of their employees, nor any of their contractors, subcontractors, or their employees, makes any warranty, express or implied, or assumes any legal liability or responsibility for the accuracy, completeness or usefulness of any information, apparatus, product or process disclosed, or represents that its use would not infringe privately owned rights. 
Contract No. W-7405-eng-26

Information Division

A SHORT GUIDE TO SDI PROFILING AT ORNL

Herbert S. Pomerance

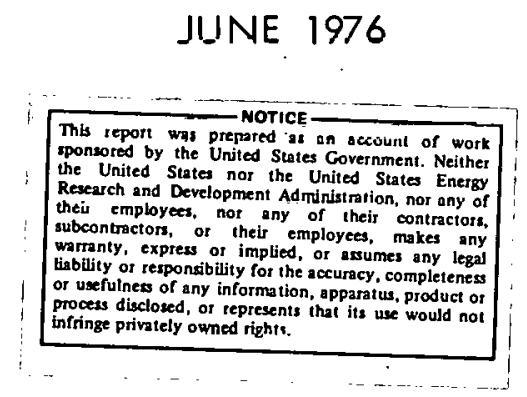

OAK RIDGE NATIONAL LABORATORY

Oak Ridge, Tennessee 37830

operated by

UNION CARBIDE CORPORATION

for the

ENERGY RESEARCH AND DEVELOPMENT ADMINISTRATTON 
THIS PAGE

WAS INTENTIONALLY

LEFT BLANK 
CONTENTS

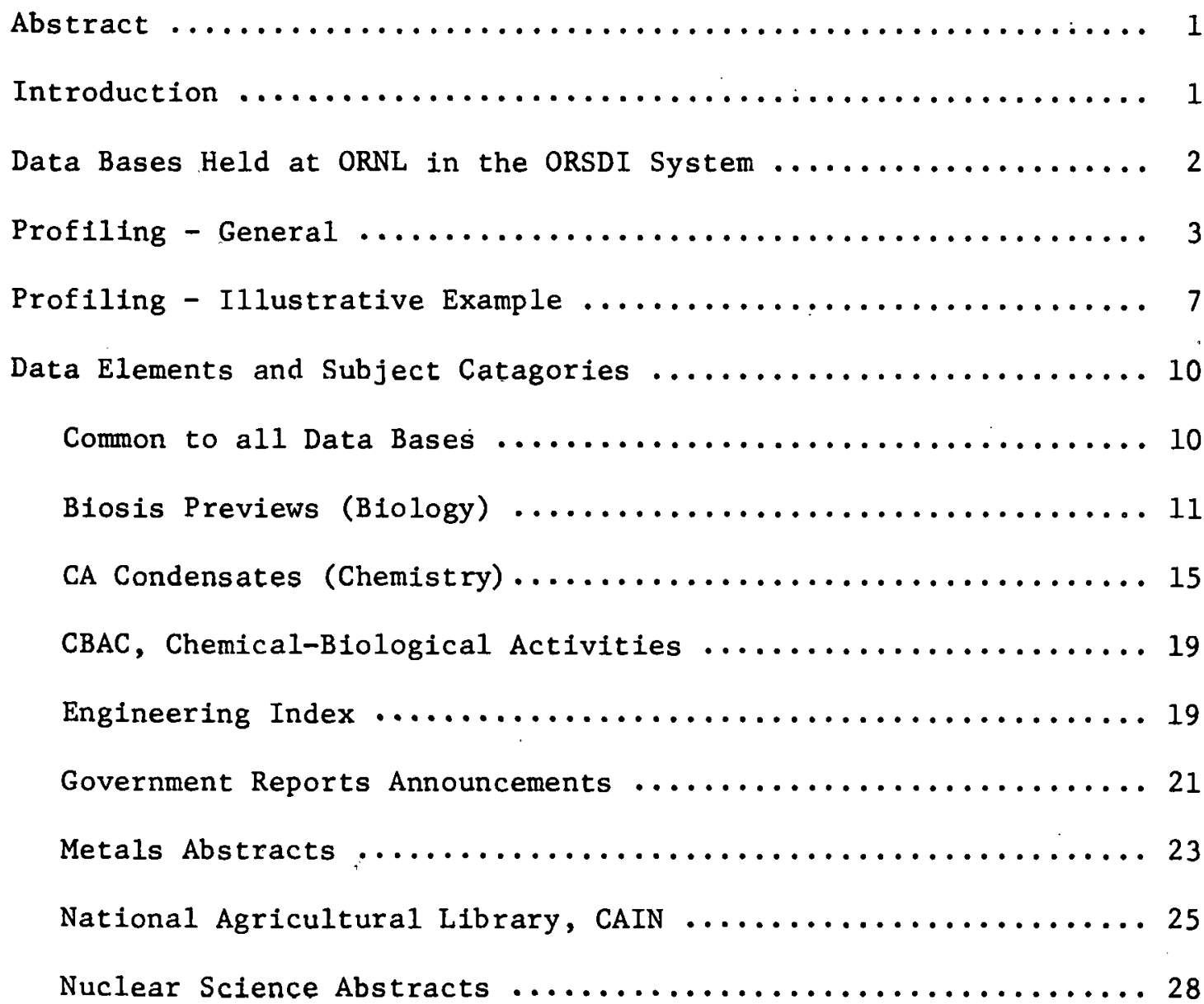




\section{ABSTRACT}

ORNL has machine-searchable data bases that correspond to printed indexes and abstracts. This guide describes the peculiarities of those several data bases and the conventions of the ORNL search system so that users can write their own queries or search profiles and can interpret the part of the output that is encoded.

\section{INTRODUCT ION}

The Information Division of ORNL supports machine searching of several indexing and abstract bases that are published on magnetic tape as well as in hard copy. The tapes are leased either by ORNL or by the Technical Information Organization of ERDA, and are processed by the ORSDI group in the Computer Sciences Division. There is no direct charge for ordinary use of the search system; the cost is borne by the Information Division.

Other machine search is also supported here. Some SDI (Selective Dissemination of Information) work on tapes not held here is bought outside ORNL. Retrospective searches can be performed on our holdings, and also on several other systems: The Recon system of ERDA; the Dialog system of Lockheed Retrieval Service; the Orbit III system of System Development Corp.; the New York Times Information Bank.

The user may use this guide to write his own query, called a search profile, or join with some one from the library reference section. In either case the profile must be submitted on standard forms in a standard way so that the operator can enter the material into the computer without further editing. This gulde suggests sources for identifying index terms or subject categories, it defines rules to be followed in entering terms and combining them, it describes briefly the several data bases and the fields in them that are generally used for search.

The materials here are not ail original. Guides for use at other stations were written by Harry Hamilton and Hilary Burton. The local material comes from Carla Giles, who directs the ORSDI group, on the computer end of the work, and from Herbert Pomerance, who is in charge of machine-based search. for the Information Division, on the information end. 
DATA BASES HELD AT ORNL FOR SEARCH IN THE ORSDI SYSTEM (March 1976)

\begin{tabular}{|c|c|c|c|c|c|}
\hline Data $\mathrm{Ba}$ & & Frequency & Earliest & Issue & Records per \\
\hline Symbol & Name & (per year) & vol. (iss) & |date & issue, 1974 \\
\hline NSA & $\begin{array}{l}\text { Nuclear Science } \\
\text { Abstracts }\end{array}$ & 24 & $25(14)$ & $7 / 71$ & 2750 \\
\hline & Chemfcal Abstracts & & & & \\
\hline $\mathrm{CAO}$ & odd Issues & 26 & $77(2.5)$ & $12 / 7 ?$ & ศศกุก \\
\hline $\mathrm{CAE}$ & even issues & 26 & $77(24)$ & $11 / 72$ & 8200 \\
\hline CBAC & Chemical-Biological & & & & \\
\hline & Activities & 26 & $13(1)$ & $1 / 71$ & 1800 \\
\hline BA & Biological Abstracts & 24 & $51(1)$ & $1 / 71$ & 6000 \\
\hline BRI & BioResearch Index & 12 & $71(1)$ & $1 / 71$ & 8000 \\
\hline GRA & $\begin{array}{l}\text { Government Reports } \\
\text { Announcements }\end{array}$ & 24 & $72(1)$ & $1 / 72$ & 2500 \\
\hline CAIN* & $\begin{array}{l}\text { National Agricultural } \\
\text { Library }\end{array}$ & 12 & & $1 / 70$ & 10000 \\
\hline MET & Metals Abstracts & 12 & $69(1)$ & $1 / 69$ & 900 \\
\hline$E I *$ & Engineering Index & 12 & $72(1)$ & $1 / 72$ & 7500 \\
\hline
\end{tabular}

*SDI service only, except by special arrangement.

This list is for batch search in the ORSDI system. The on-line systems (Recon, Dialog, SDC, NY Times) are not shown here nor are the systems separately operated by some of the ORNL information centers. 
The large machine-searchable index bases are generally derived from the magnetic tape record of the printing operation of that base; therefore, searching the magnetic tape record is similar to searching the printed record. In changing from manual searching to machine searching, the profiler in framing his query must remember that the data base generally undergoes a conversion in format and style that may not match the format of the printed issue; therefore, for an effective search the profiler should familiarize himself with the format of the tape as it is used as well as with its content. The content of the data base is often augmented in the tape version compared with the printed version with additional index terms or subject classifications.

The query must be phrased in accord with the requirements of the search system. There are several on-line interactive systems for retrospective search in use at ORNL. This guide does not directly deal with them but only with the batch searches that are the principal source of SDI search (that searches only the last tape) and the similar retrospective search that goes through all the tapes from first to last. The on-line systems use ordered indexes of the various fields (inverted files), such as alphabetical lists of authors, of index terms, of journal names or codens, of subject categories, of locations of work. The batch search uses no indexes but only the original tape converted for search purposes. Each item or record is searched in its turn for the presence of the terms in the queries. Only when the last item has been searched can there be a statement of how many hits have been found for each query.

The text search program in computer use at ORNL was first developed with NSF money at the University of Georgia. The program converts all data bases to a common search format and uses a single computer search program for all bases. The common format calls all titles TTL, calls all authors ATI (for authors inverted), calls all journal Codens CDN, and so on. A data base may also have its unique elements. For example, Biological Abstracts has two subject codes it calls Cross Code and Blosystematic Code; Nuclear. Science Abstracts uses the INIS Thesaurus terms and the INIS subject classifications. For the common 
elements variations are found. Are authors' first names spelled out, are the initials spaced with periods or closed up without periods? Are chemical element symbols used in the titles or are the chemical names spelled out? There are five-letter Codens and six-letter Codens.

Because the titles in the several bases are named TTL, it is possible to write a single search profile or query that fits all the bases and that does nothing more than search the titles for the selected keywords. The same keywords can be sought in the abstract field ABS and in the tree-index-term field F'l' in the bases that have such fields. By a convention in our search system, the name TXT includes the three fields 'I"IL, F'l' and ABS. Uf the bases now at UKNL (1976), CBAC (Chemica1-Biological Abstracts) in full and GRA (Government Reports Announcements) in part have abstracts; the others have none. Only NSA (Nuclear Science Abstracts) and its successors in 1976, Atomindex and Energy Information Data Base remain without a field called FIT. Like several other bases, NSA and EIDB use a controlled index vocabulary but for the other bases the controlled field in the ORNL conversion is also designated FIT (which may now mean free or fixed index terms) whereas for NSA the index terms are designated NST.

Although a single search profile may serve for all the bases, it may not be efficient in all of them. Aside from the controlled vocabularies there is subject indexing and each base has its own subject catagories. In the bases with only one subject assignment to an item, a subject may best be used for negation (AND NOT). In the bases with multiple subject assignments, a profile with subjects alone may be more effective than one with index terms or with title keywords.

Each index journal has its own manner of presentation of its indexes. It may use subject heading plus modifier line as in Nuclear Science Abstracts until 1972; URANIUM, analysis for boron. Or it may use coordinate indexing where all terms have equal value, as in NSA after 1972: URANIUM; BORON; QUANTITATIVE CHEMICAL ANALYSIS. Or it may use KWIC indexes (permuted words) of titles, as in Biological Abstracts. Always there is an alphabetical author index. Implicit in the tape record are not only the indexes found in the printed version 
but indexes of any other element: the year, the journal, the author's institution, the words of the title. And also implicit in the tape record are indexes by pairs of words and by triples.

Each data element in the text search system is classified as one of two types: left-anchored (LA) or free text (FT). The classification determines the manner and speed in which the data element is searched; therefore, the profiler must be aware of this characteristic for each data element he codes and structure his request accordingly. Leftanchored attributed to a data element implies that its format and content are precisely known. The match always begins with the left-most character. Before further character-by-character comparisons are made, the length of the search term is checked against the length of the data base term. If right-hand truncation is not specified and if the lengths are unequal, further comparisons are skipped and the terms are flagged as unequal. In other words, left-anchored search terms which are not specified to be truncated must match the data base term exactly. Word fragments from the data base cannot be retrieved unless the search term is truncated. Examples of left-anchored data elements are: Author Name (last name first); Coden; and Registry Number. Only suffix (righthand) truncation or no truncation can be used with LA terms. The truncation asterisk $(*)$ is interpreted to mean accept any following. character or blank.

The second type of data element is free text (FT). This type specifies a character-by-character match of all terms preceded by a blank or by a punctuation mark. Truncation on either or both ends is applicable. Examples of free-text data element are: title; abstract; and free index term or keyword.

The following examples illustrate the four possible modes of truncation.

\section{Term Explanation}

CELL Retrieves the term when it is bounded by blank spaces or by punctuation; e.g., CELI, CELL-FREE, STEM-CELL.

CELL* Retrieves the term when it is followed by any character including a blank space, and when it is preceded by a blank space or punctuation; e.g., CELL, CELL-FREE, STEM-CELL, CELLOPHANE, CELLS, CELLULAR. 
*CELL Retrieves the term when it is preceded by any character, including a blank space, and when it is followed by a blank space or punctuation; e.g., CELL, CELL-FREE, STEM-FREE, MICROCELL.

*CELL* Retrieves the term when it is preceded or followed by any character, including blank spaces or punctuation; e.g., CELL, CELL-FREE, ACELLULAR, MICELLES, CELLULOSE (the costliest in use of computer time).

Any one term for search is limited to sixty characters. Any one query (search profile) is limited to 240 terms or less depending on the length of the terms. For the search the computer treats all characters that are not alphabetic or numeric, whether in the query or in the data base, as blanks. For the printout the computer preserves all those characters, the hyphens, commas, brackets, apostrophes, etc.

The computer first seeks out a11 the terms that are asked for, then it tests the terms against the logical statement (Boolean expression) that was submitted with the query. If you ask for 'metabolism of lithium in man', you first establish three groups: 6001 = metabolism; $6002=$ lithium; $\mathrm{G003}=\operatorname{man}$. The logical statement is $\mathrm{G001} \& \mathrm{G002} \& \mathrm{G003}$, where $\&$ is the symbol for AND. If you desire other alkali metals than lithium, then $\mathrm{G0O2}$ = (lithium $\mid$ sodium $\mid$ potassium), where $\mid$ is the symbol for OR. Similarly G003 may have to be (man / woman / child/human). The convention In our system is that the OR is understood to tie all the terms within one group and need not be there written out; it must be written between groups, as in G004\& (G005|G006). If you desire metabolism of lithium in any animal except man, then the logical statement is G001 \& G002 \& G003, where $\&$ is the symbol for AND NOT.

The Venn diagrams show the relations. For two groups, where A is metabolism and $B$ is lithium:

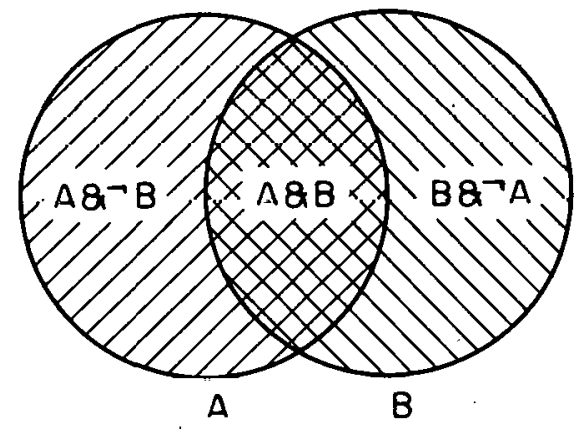


$A \&\urcorner B$ is read " $A$ and not $B$ ", that is metabolism but not lithium. $A \& B$ is read "A and $B$ ", that is metabolism and lithium (logically) or metabolism of lithium (in common speech). Three or four circles can be used to illustrate the various combinations of three or four groups. A|B is read "A or B" and is the combined area, everything to do with metabolism or with lithium or with both together.

The computer program performs AND before OR and so use parentheses for punctuation if the OR must come first. There is a difference between $(A \& B) \mid C$ and $A \&(B \mid C)$; when you write $A \& B \mid C$ without parentheses, the searih progiam will assume lie lusmer.

The terms in the profile may be words or codes, numerals or letters that belong to the data base you search. The column DEM is for the threeletter designation of the field in which that term will be found. The 'weight' is optional; it is used for sorting or as part of a logical statement. With sorting, the biggest point score is printed at the head of the list (maximum weight is $\pm 32,767$ ). You can use weighting to keep track of parts of the question; for example assign 100 to lithium, 40 to sodium, and 20 to potassium.

The illustrative proflle for USER: I. Example is not one you should copy directly. It displays some features of writing a composite query, in this case the toxicology of three elements.

a) The names of the elements are spelled out in these data bases, so symbols are not needed. The fields of search TXT may be title, keywords or abstracts in GRA; title or free index terms (keywords) in BA, BRI, CAE or CAO; title in NSA. The "TXT" in column DEM does not include the fixed index terms of NSA so we must use the DEM which is unique to NSA, "NST" (for nuclear science term.) The NST terms are left-anchored and we wish mercury, for example, to encompass mercury oxide and mercury 198; thus right truncation, represented by the asterisk, is needed. Truncation is not needed for the free-text terms searched under TXT.

b) The weights are used here for convenience to keep the elements separate in the printout. An abstract with all three elements named once each will appear first with weight 1600; a paper with 


\section{OAK RIDGE SELECTIVE DISSEMINATION OF INFORMATION PROFILE SUBMISSION \\ (PLEASE PRINT OR TYPE)}

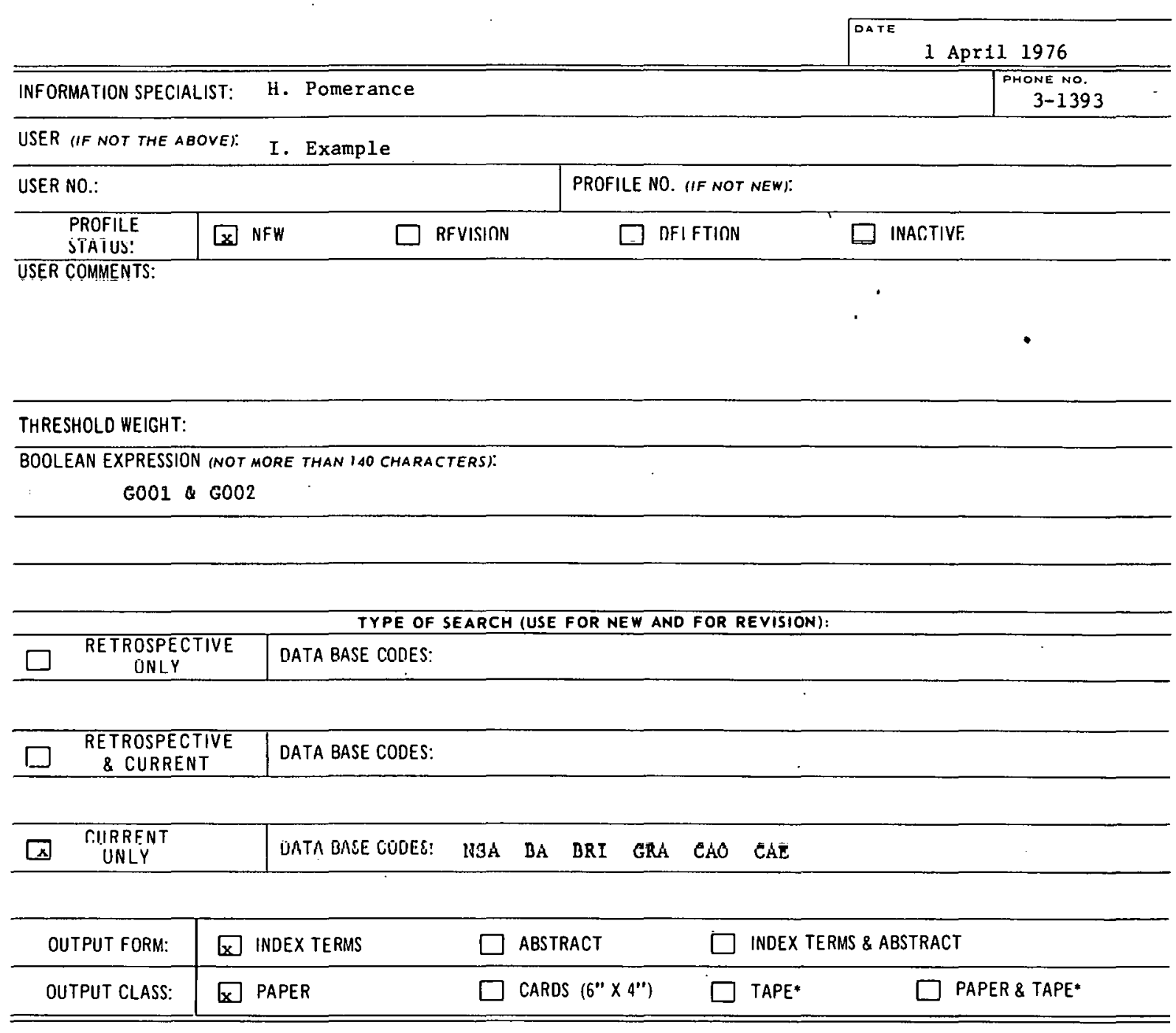

* BY SPECIAL ARRANGEMENT ONLY

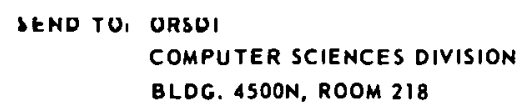

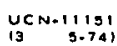


ORNL COMPUTER-BASED INFORMATION SERVICES

PROFILE SUBMISSION

User

I. Example

Page

Please print or type; indicate blank spaces in terms.

Maximum term length, 60 characters; maximum profile length, 240 terms.

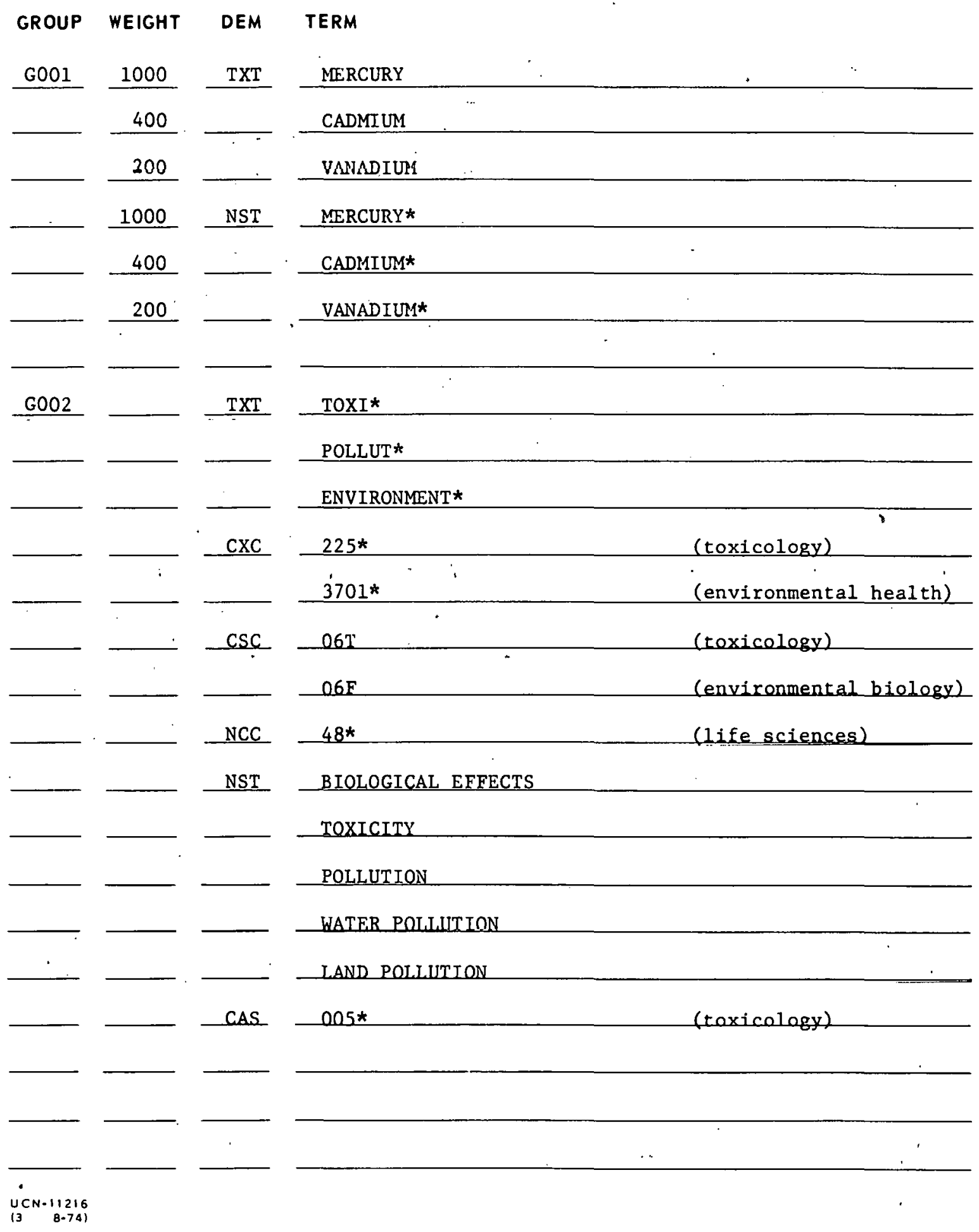


cadmium and vanadium will have weight 600 ; a paper with mercury alone will have weight 1000 .

c) In group G002 there are three word stems and some subject classes. Toxi* includes toxin, toxins, toxic, toxicology. But what if the three word stems do not appear in the title TTL or in the free index terms FIT or in the abstract ABS? For the BioAbstracts $B A$ and $B R I$ we can use the Cross Codes CXC; the topic (subject heading) corresponding to the code has been added in the example. For GRA we can use the Cosati flelds and groups CSC. For NSA we can uoc the oubject categorico NCC or the indes termo in NST. For Chemical Abstracts $\mathrm{CAE}$ and $\mathrm{CAO}$, an abstract published in Sect. 5, Toxicology, does not also have the keyword "toxicology" added although that word may appear in the title; in this case the subject field CAS and the free-text word stem "toxi*" must both be used.

Composite profiles as this one are not always efficient. Separate profiles for each data base may be better.

The following lists are a brief statement of the likely flelds of search among the large data bases now held at ORNL. The flelds that appear in most data bases are given in the first list. The three-letter designation must be used for a search profile submitted to the computer department. Left-anchored terms (LA) can't suffer left-truncation; free-text terms (FT) can. Both can suffer right-truncation. For guides to truncation, use a general dictionary, or the authority list of index terms for the data base, or the printed indexes of that base such as the permuted word index in Biological Abstracts.

Data Elements Appearing in Most Bases

Title

Free index terms, keywords, augmentation of title

Personal author

may bc Joncs $\Lambda B$; or Joncs $\Lambda B$; or Joncs, $\Lambda . B$. or Jones, A.B.; or Jones, Arthur B.

Corporate Author

Location of work
Designation Type

TTL FT

FIT FT

ATI $\quad \mathrm{L} \Lambda$

CAN FT

LOW FT 
Coden (may be 5 or 6 letters)

CDN

LA

Year of Publication of the article, usually

PDD

FT

4 digits

Abstract

$\mathrm{ABS}$

FT

Text

TXT

FT

This is used to search TTL and FIT and ABS

without writing all three separately

Volume Number of the index journal; it is found

SJV

LA in different fields in different journals

The Biosciences Information Services publish two journals. BA, Blological Abstracts, reports the journal and conference proceeding 11teratures with abstracts and indexes. BRI, BioResearch Index, has two thirds as many items but without abstract from symposia, review journals and books, trade journals, annals of science academies, institutional reports, and letters to the editor. The two have the same indexing. The titles are augmented with genus and species, with chemical names, with field of work, with method; in the printed issue the augmented title is permuted for a KWIC index. For the variant spellings and for the word breaks (such as di ethyl ether), study the printed indexes or use "A Guide to the Vocabulary of Biological L1terature" which gives the frequencies of usage of 8700 words and fragments for the years 1959-73. The "Biosystematic Code," a five-digit code, is used for taxonomic orders and larger divisions; smaller divisions, genus and species, appear in the title augmentation or in the title itself. The nearly one hundred subject classifications of the printed issues of $B A$ have been further subdivided in the "Cross Code". We use six characters, the five numerals of the code followed by a $P$ (primary) for the section in which the printed abstract appeared, by an $S$ (secondary) for subject fields nearly as important; by a $T$ (tertiary) for flelds of lesser relevance. Because truncation of a Cross Code also removes the $P . S$, and $T$. it may pay to enumerate all the desired Code numbers and use the $P$ and $S$ rather than to truncate 
the Code numbers and get the unwanted $\mathrm{T}$ t1tles.

Data Elements

Title

Augmentation of title

Author, as Goldberg A R

Biosystematic code, five digits

Cross code, five digits plus $P, S$, or $T$

Coden, five digits

BA volume number, 59 and 60 in 1975

BRI volume number, 75 in 1975

$\begin{array}{ll}\text { TTL } & \text { FT } \\ \text { FIT } & \text { FT } \\ \text { ATI } & \text { LA } \\ \text { BTC } & \text { LA } \\ \text { CXC } & \text { LA } \\ \text { CDN } & \text { LA } \\ \text { SJV } & \text { LA } \\ \text { SJV } & \text { LA }\end{array}$

\section{SUBJECT CLASSIFICATIONS AND CROSS CODES IN BIOABSTRACTS}

The Subject Classification Guide which appears as the Table of Contents in each issue of Biological Abstracts or BioResearch Index is alphabetical. The hundred subjects are further divided in the Cross Codes and assigned numbers in accord with a logical grouping. The table below in numerical order shows an abbreviated name of the subject for each numerical code. It is Intended for reading output, not for writing a profile. The five-digit numbers shown here are each the first of a series but may themselves not be usable numbers.

\begin{tabular}{llll} 
Subject & lode & Subject & Gode \\
\cline { 2 - 4 } general & 00500 & biochem-clinical & 10010 \\
methods, apparatus & 01000 & -utliods & 10050 \\
evolution & 01500 & -studies & 10060 \\
cytology, cytochem & 02500 & replication,... & 10300 \\
gencticg & 03500 & biophystos & 10500 \\
mathematical & 04500 & external effects & 10600 \\
anthropology & 05000 & enzymes & 10800 \\
social biology & 05500 & anatomy, histology & 11100 \\
aero; underwater & 06000 & chordate body, genl & 11300 \\
subterranean & 06400 & physiology, genl & 12000 \\
radiation biology & 06500 & movement & 12100 \\
periodic, circadian & 07200 & pathology & 12500 \\
ecology & 07500. & metabolism & 13000
\end{tabular}




$\begin{array}{ll}\text { nutrition } & 13200 \\ \text { food technology } & 13500 \\ \text { digestive sys } & 14000 \\ \text { cardiovascular sys } & 14500 \\ \text { blood, fluids } & 15000 \\ \text { urinary sys, secreti } & 15500 \\ \text { respiratory sys } & 16000 \\ \text { reproductive sys } & 16500 \\ \text { endocrine sys } & 17000 \\ \text { muscle } & 17500 \\ \text { bone, connectives } & 18000 \\ \text { coelomic, mesenteries } & 18200 \\ \text { integumentary sys } & 18500 \\ \text { dental, oral biology } & 19000 \\ \text { sense organs } & 20000 \\ \text { nervous sys } & 20500 \\ \text { psychiatry } & 21000 \\ \text { pharmacology } & 22000 \\ \text { immunization } & 22100 \\ \text { toxicology } & 22500 \\ \text { temperature } & 23000 \\ \text { neoplasms } & 24000 \\ \text { gerontology } & 24500 \\ \text { pediatrlcs } & 25000 \\ \text { embryology } & 25500 \\ \text { animal production } & 26500 \\ \text { poultry production } & 27000 \\ \text { laboratory,animals } & 28000 \\ \text { microoraanisms } & 29500 \\ \text { bacteriology, general } & 30000 \\ \text {-morphol, cytol } & 30500 \\ \text {-physlol, biochem } & 31000 \\ \text {-genetics (also virus) } & 31500 \\ \text { microbiology methods } & 32000 \\ \text {-ultrastructure } & 32300 \\ \text { tissue culture } & 32500 \\ & \\ & \end{array}$

$\begin{array}{ll}\text { in vitro studies } & 32600 \\ \text { virology } & 33500 \\ \text { immunology (chem) } & 34500 \\ \text { immunology (parasit) } & 35000 \\ \text { allergy } & 35500 \\ \text { microbiology, medical } & 36000 \\ \text { public health } & 37000 \\ \text { veterinary science } & 38000 \\ \text { chemotherapy microbio } & 38500 \\ \text { food and ind. microbion } & 39000 \\ \text { disinfection } & 39500 \\ \text { soilmicrobiology } & 40080 \\ \text { paleobotany } & 50000 \\ \text { palynology } & 50100 \\ \text { systematic botany } & 50500 \\ \text { morphology of plants } & 51000 \\ \text { physiol, biochem plants } & 51500 \\ \text { economic botany } & 52000 \\ \text { agronomy } & 52500 \\ \text { soil science } & 52800 \\ \text { horticulture } & 53000 \\ \text { forestry } & 53500 \\ \text { pharmaceutical botany } & 54000 \\ \text { phytopathology } & 54500 \\ \text { pesticides, herbicides } & 54600 \\ \text { economic entomology } & 60000 \\ \text { parasitology } & 60500 \\ \text { sanitary entomology } & 61000 \\ \text { chordata, systematic } & 62500 \\ \text { animal distribution } & 62800 \\ \text { paleozoology } & 63000 \\ \text { invertebrata, system. } & 63500 \\ \text {-compar., morphol. } & 64000 \\ \text {-structure } & 64200 \\ \text { paleobiology } & 64500 \\ \text { geological periods } & 64700 \\ & \\ & \end{array}$

BIOSYSTEMATIC CODES (TAXONOMY) IN BIOABSTRACTS

The major divisions of the Biosystematic Code are summarized here as phyla and classes, and as orders within Mammalia. The full 27-page list shows the taxonomic orders in alphabetical array within each phylum and with their codes in ascending numerical order; within Mammalia the finest division is the family. This list is intended as a table of contents for the complete list and for reading output. In 
a search profile you must truncate these numbers to search a whole class (or family).

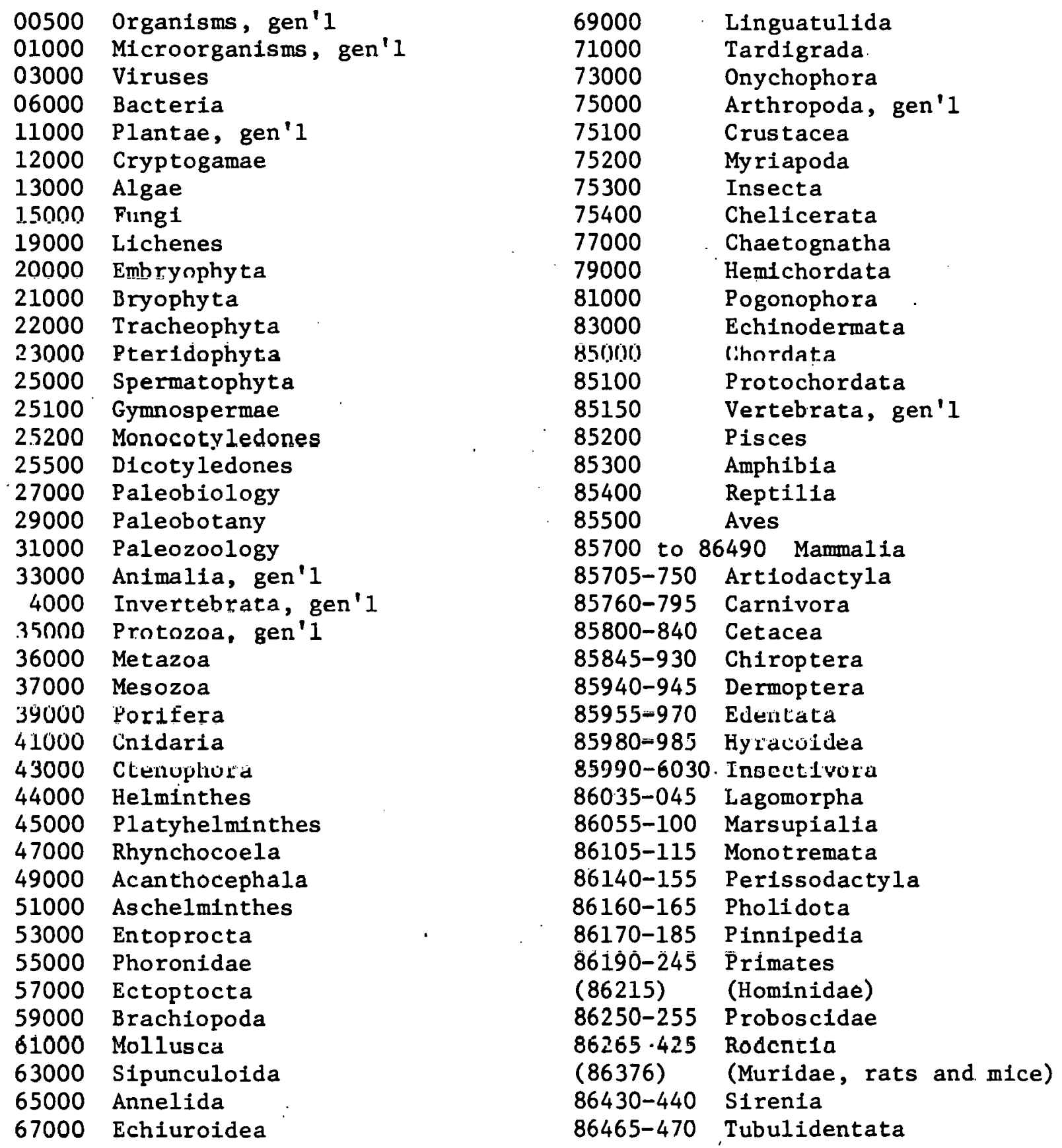


CA Condensates

$\mathrm{CAE}$ and $\mathrm{CAO}$

This tape corresponds to the weekly 1ssues of Chemical Abstracts (CAO in odd weeks, CAE in even weeks). Another set of tapes (CASIA and CAISF, not used by us) corresponds to the volume indexes that include the analytical subject index, the formula index, the substance index. In CA Condensates the title, the section assignment and the keywords are all that are avallable for subject searching. Each item is assigned to one or several of the sections, shown below, and to their subdivisions defined in "Subject Coverage and Arrangement of Abstracts by Sections." Word frequencies, phrases from the titles, and key-lettersin-context (KLIC) for the two years 1973-74 are found in the microfiche publication "CA Condensate Search Alds."

For the keywords upon which most SDI searches depend, CA makes the following statement.

The purpose of this index is to provide quick entry into the subject content of the abstracts, regardless of the particular CA section in which the abstracts occur. One or more keyword entries are derived from the title, text, or context of the abstract. There is no specific relationship between the keyword phrases in the Keyword Index and the much more detailed index entries which appear in the subsequent $C A$ Volume Indexes for the same abstract. No major effort has been directed toward standardization of terms in the Keyword Index. Synonyms, however, are not usually included as additional keywords for the same abstract. For example, if "ethylene oxide" is the keyword phrase chosen for an abstract concerning ethylene oxide, "oxirane" is not also used. Abbreviations and acronyms employed in keyword phrases are the same as those listed in the introduction to $\mathrm{CA}$, issue No. 1 of the current volume, or in the latest Index Guide. Single-letter abbreviations, those that contain internal punctuation (for example, a.c., m.p.), and abbreviations that spell a word are not used. For complex organic compounds the basic structural unit is used as a keyword entry. The name of the complete compound may also be added, e.g., "phenanthrene" and "Isopropylphenanthrene." All concepts and substance names, whether of specific substances or classes of substances, are given in the singular form. Thus, the word "phenol" may refer to the specific substance phenol or to a class of substances of which phenol is the simplest example. A chemical substance name or class name standing alone as a keyword implies preparation of that particular chemical species. The standard positional and isomeric locants are rarely used in keywords, ciscinnamic acid appears in the Keyword Index at "cinnamic acid" and 2-butanol at "butanol." 
The keywords are often abbreviated. In each volume of $\mathrm{CA}$ is to be found a list of 350 abbreviations and symbols that are used in the abstracts; e.g., concn for concentration. Not all of them are abbreviated when used as keywords and only inspection of the keywords in a printed issue can be depended on.

Data Elements

Title TTL, corporate author CAN, location of work LOW, year of publication PDD

Author, as Hagstrum HD ATI LA

Keywords FIT FT

Chemical Abstracts section as $0 a b *$, section and subsection as 0ab0cd* CAS LA

Coden, 5 characters plus a CA check character usually truncate after the fifth CDN LA

CA volume number, 082 and 083 in 1975 SJV LA

The section numbers here are for the printed issues of Chemical Abstracts and for magnetic tape issues of CA Condensates. Many of these sections reappear in magnetic tape subset versions that carry the full abstract and all the deep indexing of the volume indexes; the subsets are indicated for 1975 although only one of them is now in use at ORNL.

CAO (odd issues)

Biochemistry Sections

1. Pliarmacudy

2. Hormone Pharmacology $\ldots \ldots \ldots \ldots \ldots \ldots \ldots \ldots$

3. Biochemical Interactions $\ldots \ldots \ldots \ldots \ldots \ldots$

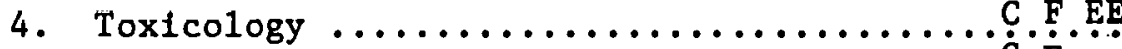

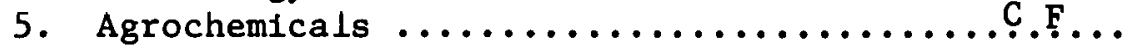

6. General Biochemistry $\ldots \ldots \ldots \ldots \ldots \ldots \ldots \ldots \ldots \ldots$

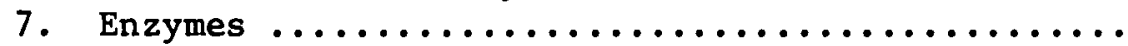

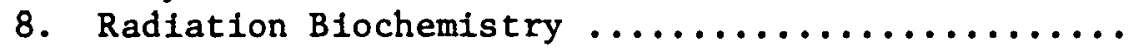

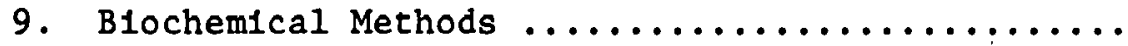

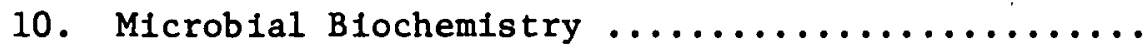

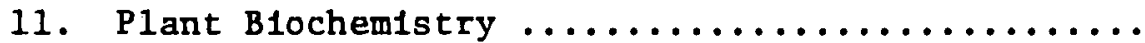

12. Nonmamnalian Biochemistry $\ldots \ldots \ldots \ldots \ldots \ldots \ldots$

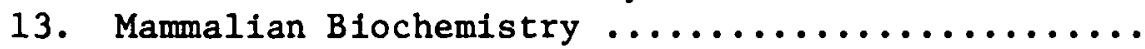

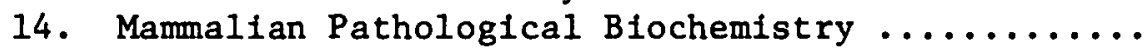

15. Immunochemistry 
16. Fermentations $\ldots \ldots \ldots \ldots \ldots \ldots \ldots \ldots \ldots \ldots \ldots \ldots$

17. Foods $\ldots \ldots \ldots \ldots \ldots \ldots \ldots \ldots \ldots \ldots \ldots \ldots \ldots \ldots \ldots \ldots \ldots$

18. Animal Nutrition $\ldots \ldots \ldots \ldots \ldots \ldots \ldots \ldots \ldots \ldots \ldots \ldots$

19. Fertilizers, Soils, and Plant Nutrition ..........EE

20. History, Education, and Documentation ...........

\section{Organic Chemistry Sections}

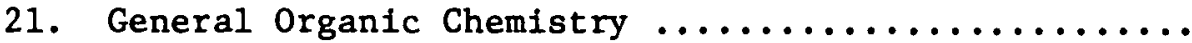

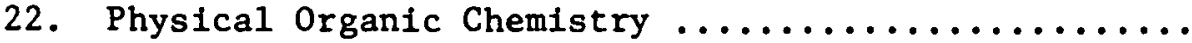

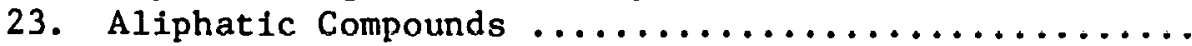

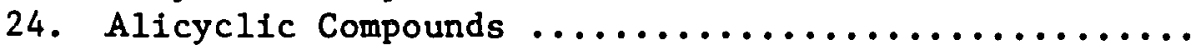

25. Noncondensed Aeromatic Compounds ..............

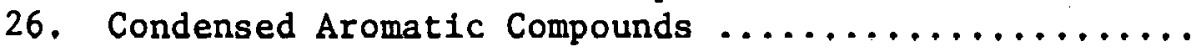

27. Heterocyclic Compounds (One Hetero Atom) .........

28. Heterocyclic Compounds (More Than One

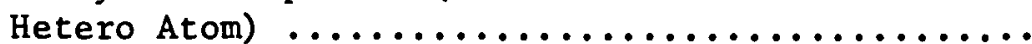

29. Organometallic and Organometalloidal

Compounds

30. Terpenoids

31. Alkaloids

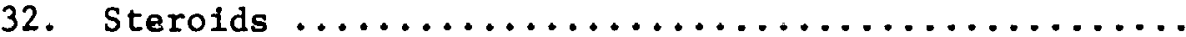

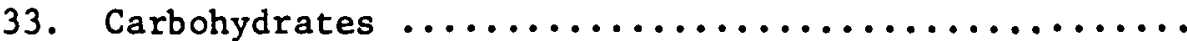

34. Synthesis of Amino Acids, Peptides, and

Proteins

\section{CAE (even issues)}

Macromolecular Chemistry Sections

35. Synthetic High Polymers ................ P M

36. Plastics Manufacture and Processing ...........

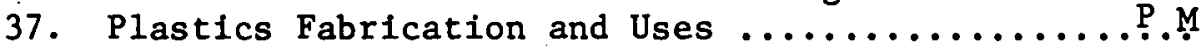

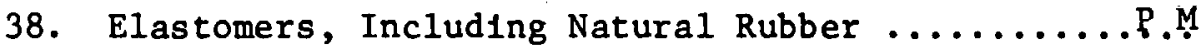

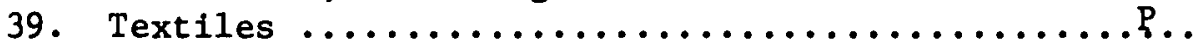

40. Dyes, Fluorescent Whitening Agents, and

Photosensitizers .................. $\Gamma$

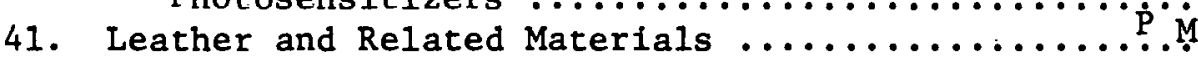

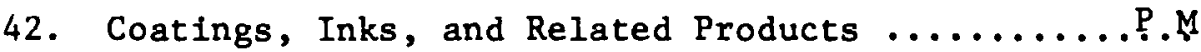

43. Cellulose, Lignin, Paper, and Other Wood

Products $\ldots \ldots \ldots \ldots \ldots \ldots \ldots \ldots \ldots \ldots \ldots \ldots \ldots$

44. Industrial Carbohydrates $\ldots \ldots \ldots \ldots \ldots \ldots \ldots \ldots \ldots$

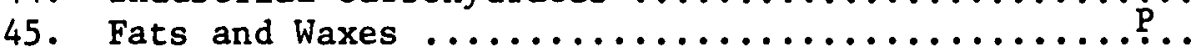

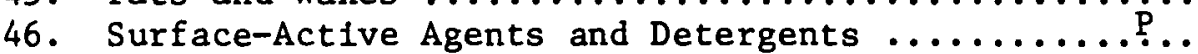

Applied Chemistry and Chemical Engineering Sections

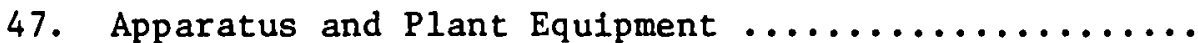

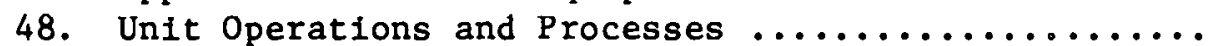

49. Industrial Inorganic Chemicals $\ldots \ldots \ldots \ldots \ldots \ldots \ldots$

50. Propellants and Explosives ................ En

51. Fossil Fuels, Derivatives, and Related

Products .......................... En 
52. Electrochemical, Radiational, and Thermal

Energy Technology ........................ En

53. Mineralogical and Geological Chemistry ...........

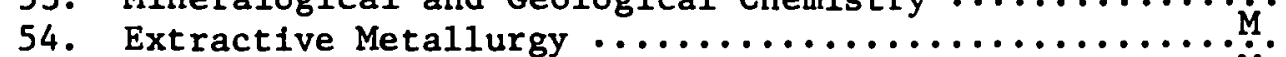

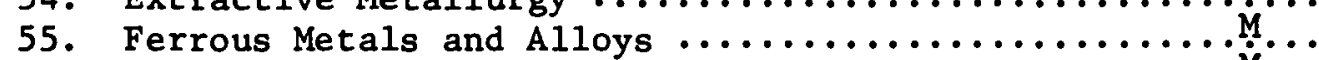

56. Nonferrous Metals and Alloys $\ldots \ldots \ldots \ldots \ldots \ldots \ldots \ldots \ldots$

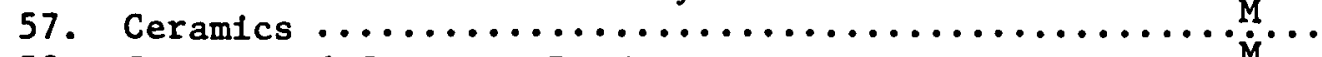

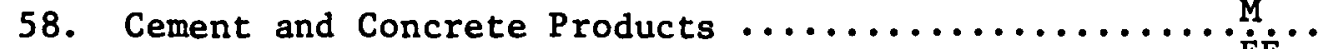

59. A1r Pollution and Industrial Hygiene $\ldots \ldots \ldots \ldots \ldots \ldots$ EE ..

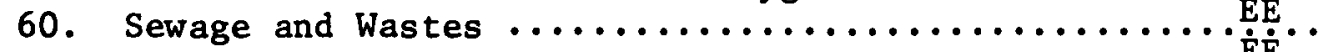

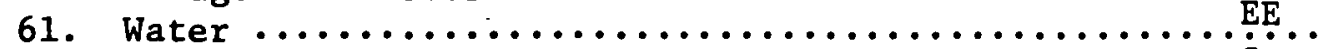

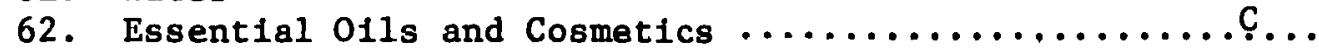

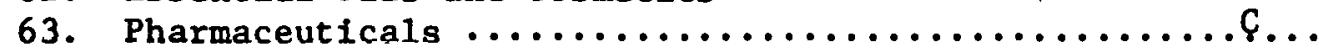

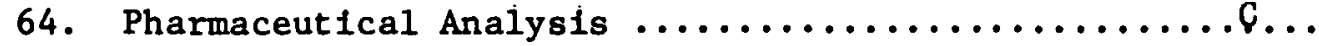

Physical and Analytical Chemistry Sections

65. General Physical Chemistry ....................

66. Surface Chemistry and Collo1ds ...................

67. Catalysis and Reaction Kinetics ..................

68. Phase Equilibriums, Chemical Equilibriums,

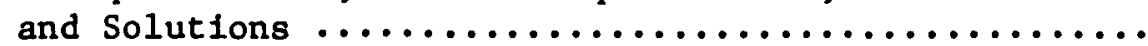

69. The rmodynamics, The rmochemistry, and Thermal Properties ..................... En

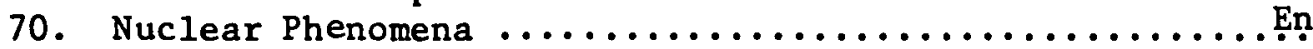

71. Nuclear Technology $\ldots \ldots \ldots \ldots \ldots \ldots \ldots \ldots \ldots \ldots \ldots$.

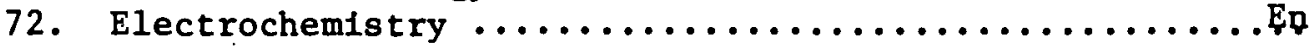

73. Spectra by Absorption, Emission, Reflection, or Magnetic Resonance, and Other Optical ...........

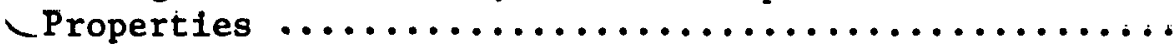

74. Radiation Chemistry, Photochemistry, and

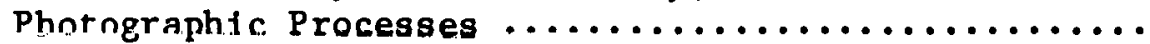

75. Crystallization and Crystal structure $\ldots \ldots \ldots \ldots \ldots \ldots$

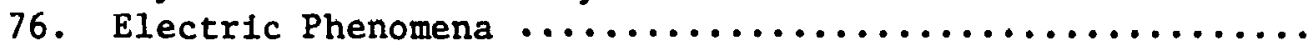

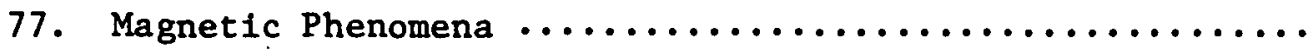

78. Inorganic Chemicals and Reactions $\ldots \ldots \ldots \ldots \ldots \ldots \ldots \ldots$

79. Inorganic Analytical Chemistry $\ldots \ldots \ldots \ldots \ldots \ldots \ldots \ldots$

80. Organic Analytical Chemistry $\ldots \ldots \ldots \ldots \ldots \ldots \ldots \ldots$

$\mathrm{C}=\mathrm{CBAC}$, Chemical-Biological Activities

$\mathrm{EE}=\mathrm{Ecology}$ and Environment

En = Energy

$\mathrm{F}=$ Food and Agricultural Chemistry

$\mathrm{M}$. = Materials

$\mathrm{P}=$ POST, Polymer Sclence and Technology 
Chemical-Biological Activities CBAC

This name is now used by Chemical Abstracts for eight of its eighty sections: 1-5, 62-64. It differs from Chemical Condensates, which has all eighty subject sections, by carrying the full abstract, the preferred names and molecular formulas and Registry numbers of all the reported compounds, and beginning in 1975 the subject headings (fixed language) and modifier lines (free language) that are used in the analytical subject index which is published twice a year. The subject section numbers and the keyterms of each issue of Chemfcal Abstracts are also included in CBAC, which appears biweekly. Registry numbers are published in book form; also the "Name-Match" computer program at ORNL can be used to find the Registry number together with the preferred name and all the trivial names from any one name. Chemical symbols are not used in title or text, only full spellings; unlike BioAbstracts there are no spaces between identifiable fragments of compound names.

\section{Data Elements}

Al1 the data elements of CA Condensates. Additional elements are:

Molecular formulas, Hill system MFS FT

Chemical Abstracts preferred name CNA FT

CA Registry number, nine digits with leading zeros

REG LA

CBAC volume number, use the $C A$ volume number

SJV LA

Abstract

ABS

FT

Engineering Index

EI

Engineering Index publishes three printed services and one magnetic tape service. They all carry the same citation record and abstract but the index terms and the serial numbers are not the same in all. The weekly Card-A-Lert service for current awareness uses a three-level subject classification. The Engineering Index Monthly (Vol, 12 appeared in 1974) and Engineering Index Annual (Vol. 73 in 19.74) group the 
abstracts by subject heading and subheading taken from another 1 ist. The Annual cumulates the abstracts from the Monthly but with a revised serial number. The magnetic tape version, Compendex (for CoMputerized ENgineering indEX), carries all the information of the three printed issues except for the serial number in the Annual, because it is derived from the tape used in photocomposition of the Monthly and of Card-A-Lert. In Compendex the volume number, as in EI Monthly, is the last two digits of the year (Vol. 74 in 1974).

Selection criteria are established both according to subject matter and to worth. Engineering is the practical application of science. Marginal matter, mostly in pure chemistry, pure physics, pure geology, sociology and biology, is excluded. Articles which are purely commercial, very elementary, editorials, announcements, news items are excluded. The areas of acceptance change as the areas of concern to society change. Pollution, urban problems, safety, food technology, solar energy, coal liquefaction are among more recent areas of engineering.

In 1974 Engineering Index carried about 90,000 abstracts. There were two thirds that many items in 1969, the first year of Compendex. The articles were found in 2000 journals and 1200 proceedings of conferences and symposiums. The journals of American engineering societies are given express handilng and cumplete cuvelage. The published list of the 2000 journals with titles and Coden is called PIE (Publications Indexed for Engineering).

The subject classifications for the current awareness service (Card-A-Lert) divide all of engineering by a three-digit code into 6 disciplines (first digit), into 38 groups (first two digits), and into 167 divisions (a11 three digits). The guide to Card-A-Lert shows both the codes with their definitions and an alphabetical inversion of the 9000 terms used in the definition of the codes.

The Index Terms, the second indexing scheme, come from SHE (Subject Headings for Engineering), a controlled vocabulary with 12,000 authorized combinations of index headings and subheadings. Generally several headings are applied to each item. The Thesaurus of Engineering Terms, published by the Engineers Joint Council, is not directly used 
by Engineering Index for vocabulary control.

Free-language index terms are occasionally assigned; if used the rules permit no more than five for one article. The terms may come from the title or abstract.

The scope of Engineering Index is shown by the titles of the six disclplines used in the Card-A-Lert service: 400, Civil- EngironmentalGeological- Bloengineering; 500, Mining- Metals- Petroleum- Fuel Engineering; 600, Mechanical- Automotive- Nuclear-Aerospace Engineering; 700, Electrical- Electronics- Control Engineering; 800, Chemica1Agricultural- Food Engineering; 900, Industrial Engineering- ManagementMathematics- Physics- Instruments.

\section{Data Elements}

Title TTL, year of publication PDD,

Subject code (Card-A-Lert), as A522 SCC FT Controlled vocabulary from SHE FIT FT

Free-language index terms (occasional) FIT FT

Author, as Smith, R.S. ATI LA

Abstract ABS FT

EI volume number (tape issue), $\quad$ SJC

Government Reports Announcements . GRA

This journal was formerly U.S. Government Research and Development Reports. Indexing is pluralistic. For subject categorles, the publisher NTIS must use the twenty-two Cosati fields with their groups (dates from the 60s). NTIS uses another twenty-three fields for 1ts WGS - Weekly Government Abstracts (dates from the 70s). What NTIS calls descriptors (index terms from an authority list) are assigned by NASA from the "INIS Thesaurus" for its reports, by the DDC from its "Thesaurus of Engineering and Science Terms" for Department of Defense reports, and by NTIS for the remainder from the quite similar "Thesaurus of Engineering Terms." Additionally NTIS adds identiffers (free index terms or keywords) to all the reports. Our text search program combines 
the descriptors and identifiers under FIT. Abstracts published by

NASA in STAR or by the AEC in ERDA are referred to but not recorded on

the tape; for other reports there is an abstract on the tape.

\section{Data Elements}

Title TTL, Corporate author CAN, Publication year PDD,

Author, as Ferguson, Edward G.

ATI LA

Descriptors and identifiers, index terms

FIT FT

Subject fields and groups, Cosati or NTIS

(a leading zero is used for flelds less than 10)

$\operatorname{CSC} \quad \mathrm{FT}$

Abotract

ABS FT

Report number

RNO LA

Contract grant number

CNO FT

The NTIS document serial number (accession no.)

DSN LA

Document ava1lability

DAV FT

Volume number of GRA, 75 in 1975

SEC FT

\section{Subject Classifications in GRA}

In the printed issues of GRA, the Cosati field and group assignments are shown; each 1tem has at least one. NuL all items appear in WGA, Weekly Government Abstracts but those that do carry one or more NTIS field and group assignments. The tape issue carries both sets of numbers. The list below shows only the fields (divisions) and not the groups (subdivision).

\section{Cosati ficldo}

01. Aeronautics

02. Agriculture

03. Astronomy and Astrophysics

04. Atomspheric Sclences

05. Behavioral and Social Sciences

06. Biological and Medical

07. Chemistry

08. Earth Sciences and Oceanography

09. Electronics and Electrical Engineering 
10. Energy Conversion (non-propulsive)

11. Materials

12. Mathematical Sciences

13. Mechanical, Industrial, Civil and Marine Engineering

14. Methods and Equipment.

15. Military Sciences

16. Missile Technology

17. Navigation, Communications, Detection, and Countermeasures

18. Nuclear Science and Technology

19. Ordnance

20. Physics

21. Propulsion and Fuels

22. Space Technology

\section{NTIS fields}

45. Communications

46. Physics

47. Ocean Technology and Engineering

48. Natural Resources

49. Electrotechnology

50. Civil and Structural Engineering

57. Medicine and Biology

62. Computers, Control and Information Theory

68. Environmental Pollution and Control

70. Administration

71. Materials Sciences

85. Transportation

88. Library and Information Sciences

89. Building Technology

90. Government Inventions for Licensing

91. Urban Technology

92. Behavior and Society

94. Industrial and Mechanical Engineering

95. Blomedical Technology and Englneering

96. Business and Economics

97. Energy

98. Agriculture and Food

99. Chemistry

Metals Abstracts and Netals Index MET

The American Society for Metals and the Institute of Metals (London) jointly publish a monthly index of metallurgy and metals. All articles in 100 journals are indexed and another 1000 journals are used selectively to give 28,000 entries a year, half from English-language sources and half from foreign-language sources. Ninety per cent of the entries come 
from journals, five per cent from reports and five per cent from monographs or proceedings. There are no patents.

The bibliographic citations in Metals Abstracts and the index headings in Metals Index are produced from the magnetic tape, The index headings are selected from a controlled vocabulary "Thesaurus of Metallurgical Terms" and are most often heading/subheading pairs; for example, Oxygen/sorption. On the average six index headings are applied to one citation. In addition there are alloy designations, used for publication of Alloys Index, that allow a finer division of the alloy types along with a statement of compound, alloy, or system.

To allow us to distinguish between an element and 1ts mixtures, the index pairs are separated by a comma plus a blank space; 'cobalt*" will retrieve all references beginning with cobalt, but 'cobalt, $\not * '$ (where b means a single blank space) will disqualify the two-word phrases with cobalt. Unfortunately, the pair 'cobalt, alloying element' or the pair 'cobalt, binary system' confuse the matter of whether cobalt followed by a comma is pure. Only one subject classification is assigned to an abstract; the two-digit number code for the subject is used as the first two digits of the accession number.

\section{EUBJECT CLASSIFICATTONS}

11 Constitution

12 Crystal Properties

13 Lattice Defects

14 Structural Hardening

15 Physics of Metals

16 Irradiation Effects

21 Metallography

22 Test1ng aild Control

23 Ansiygia

31 Mechanical Properties

32 Physical Properties

33 Electrical and Magnetic Phenomena

34 Chemical and Electrochemical. Properties

35 Corrosion

41 Ores and Raw Materials
42 Extraction and smeleing

43 Refining and Purification

44 Physical Chemistry of Extraction and Refining

45 Ferrous Alloy Production

46 Non-Ferrous Alloy Production

51 Foundry

52 Working (Forming)

53 Machining

54 Powder Téchnology

55 Joining

56 Thermal Treatment

57 Fininshing

58 Metallic Coating

61 Engineering Components and Structures

62 Composites 
63 Electronic Devices

71 General and Non-Classified

72 Special Publications

$\underline{\text { Data }}$ Elements

Title TTL, year of publication PDD, Author, as Farrell, D.E. ATI LA

Index term FIT FT

Suhjert classification; as 21 3JA LA

Journal title abbreviation; no Coden PRC FT

Volume number, as 1975 in 1975 SJD FT

National Agricultural Library CAIN

The CAIN tapes (CAtaloging and INdexing) are used monthly to print two 1ndexes. The "Bibliography of Agriculture" (Oryx Press) is a monthly index to the periodical 1iterature received at NAL. The "National Agricultural' Library Catalog" (Rowman and Littlefield) is a monthly catalog of books, new serfals, translations and other things. Neither has abstracts or Index terms. Each item is assigned to one (rarely more) subject category from a list of 63 common and 7 infrequent categories. To perhaps one fourth of the items one or two words, subfect phrase or a genus-species name, are added either to the title or to a separate Index tcrm 1ist. Forelgi tilles are translated into tinglish; both are searchable. The call numbers that appear on the tape record are an Internal assignment in the NAL library and are different from the 1dentification numbers in the printed issues of CAIN. Also the April CAIN tape carries the items that appear in the May "Bibliography."

The CAIN tape, but not the "Bibliography" or "Catalog," is extended to include citations compiled by the Food Nutrition Information Center and citations from the "American Bibliography of Agricultural Economics." These are indexed and abstracted, unlike the direct NAL cltations. Food and Nutrition citations can be recognized by F\&N following the NAL call number (e.8., HD366.R30 F\&N) and can be separately searched for by use 
of the field NAL. They are assigned to the CAIN categories. The Agricultural Economics citations are assigned to three CAIN categories and to six additional categories.

\section{Data Elements}

Title, including some augmentation

For retrospective search before 7402 , use both TTL and TFL

Title in foreign language TTL FT

Other augmentation TFL FT

Author, as Jones Arthur B FIT LA

or Jones A B or Jones A

Subject classification, six digit code

ATI

LA

Location of work CCC LA

Year of publication of article or book, as 1974

LOW FT

Library call number, as TX341.J6 F\&N $\mathrm{RJ} 1 . \mathrm{A} 453$

Abstract (for Food Nutrition, Agric. Econ.) ABS FT

SUBJECT CATEGORIES AND SUBJECT CODE'S IN 'CAIN', 1971 tu date

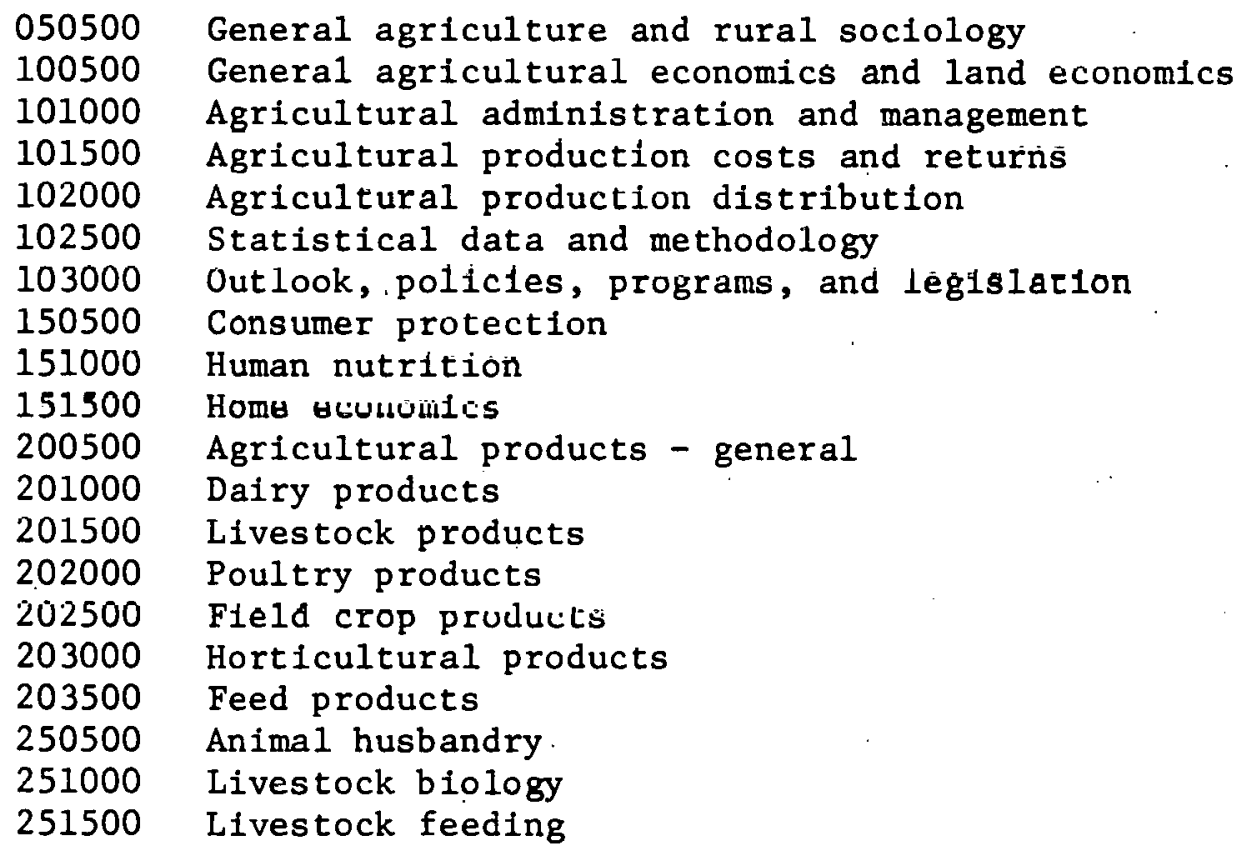




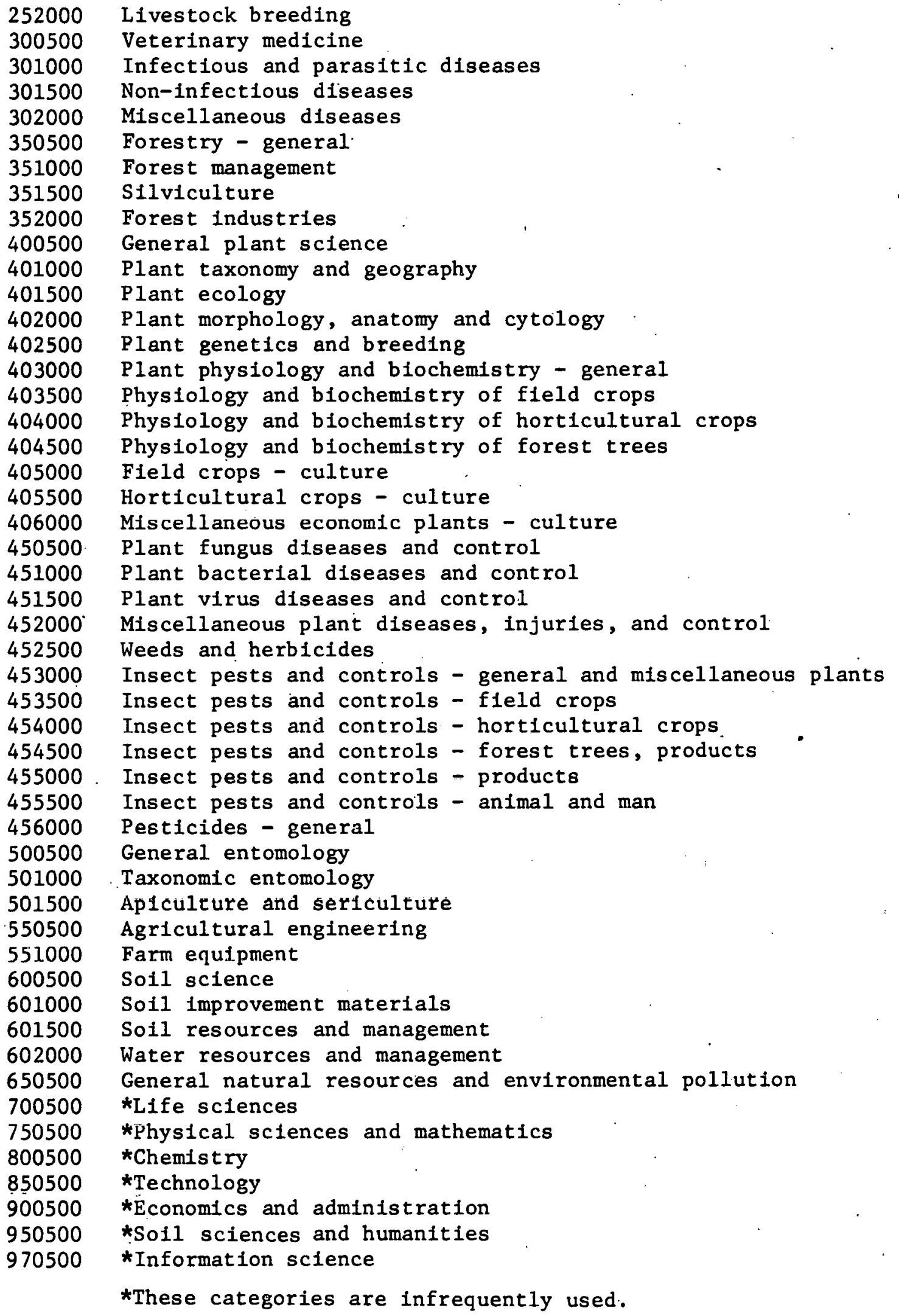


Supplementary Subjects for "Agricultural Economics"

1010* Agricultural marketing

1020* Agricultural policies and programs

1030* Agricultural products, demand, supply and prices

1040* Food and consumer economics

1050* Foreign development

1060* Production economics and farm management

1070* Regional and human development

1080* Resource economics

1090* General

Nuclear Science Abstracts NSA

Al1 but the text of the abstract appears un the magnetic tape version of this semimonthly journal. The subject categories, a fivedigit code, come from the "Extended Subject Arrangement of Material in NSA (TID-26500)"; two or three subjects are frequently assigned to an Item but only from 1975. The coordinate index terms come from the controlled list in the "INIS Thesaurus-INIS-13". But be careful; in progress reports the division by chapters in the indexing (splits) is not recognized by the computer and false drops come from the first profile term in one chapter, the second term in another.

\section{Data Elements}

Title TTL, Location of work LOW, Corporate author CAN, year of publication PDD

Author, as Parsons, R. A. (from 1974) ATI LA

Reporc number

RNO LA

Index terms (use right truncation before 1974)

NST LA

NSA subject codes, five digits (four before 1974)

NCC LA

Contract grant number CNO FT

Coden, five digits CDN $\quad$ LA

NSA volume number, 31 and 32 in 1975 SJV LA 
NSA will not be published after June 1976. The nuclear science already appears in "Atomindex" published by the International Atomic Energy Agency with the same standards as NSA. The general field of energy, and including nuclear power, appears in EIDB (Energy Information Data Base) published by ERDA with the same standards as NSA. 
THIS PAGE

WAS INTENTIONALLY

LEFT BLANK 
ORNL/TM-5484

INTERNAL DISTRIBUTION

1. A. A. Brooks

2. J. R. Buchanan

3. M. M. Cardwell

4. Z. Combs

5. T. F. Connolly

6. R. R. Dickison

7. W. B. Ewbank

8. J. R. Ferguson $-\mathrm{K}-25$

9. J. M. Fielden

10. H. B. Gerstner

11-15. C. A. Giles

16. J. S. Gillen

17. J. C. Gillespie (PAD)

18. M. P. Guthrie

19. A. S. Hammons

20. C. F. Holoway

21. J. K. Huffstetler

22. H. T. Kemp

23. H. F. Kuhns

24. L. R. Lewis

25. A. S. Loeb 1

26. W. B. Malthouse

27. B. F. Maskewitz

28. H. J. McLain

29. H. F. McDuffie
30. C. R. Nook

31. K. M. Olsen

32. J. H. Owings

33. L. J. Peck

34. H. Pfuderer

35-56. H. S. Pomerance

57. C. E. Price

58. L. W. Rickert

59. M. D. Shelby

60. V. A. Singletary

61. C. S. Strickler

62. D. K. Trubey

63. G. U. Ulrikson

64. L. H. Veach

65. H. S. Warren

66. J. S. Wassom

67. J. A. Watts

68. D. A. Wilkes

69. S. L. Yount

70-71. Central Research Library

72-91. CSD Library

92. Document Reference Section- $\mathrm{Y}-12$

93-94. Laboratory Records

95. Laboratory Records - RC

96. ORNL Patent Office

\section{EXTERNAL DISTRIBUTION}

97. Research and Technical Support Division, Oak R1dge Operations, Oak Ridge, Tennessee 37830

98. D. H. Moneyhun, Technical Information Center, Oak Ridge, Tennessee 37830

99. D. E. Bost, Technical Information Center, Oak Ridge, Tennessee 37830

100. T. E. Hughes, CXXI A15204, Office of Public Affairs, Energy Research and Development Administration, Washington, D.C. 20545

101-127. Technical Information Center, Oak Ridge, Tennessee 37830 